\title{
Identifikasi Isolat Khamir Berpotensi sebagai Agens Antagonis dan Uji Produksi Toksin Hemolisin
}

\author{
Sri Hartati ${ }^{1 *}$, Suryo Wiyono ${ }^{2}$, Sri Hendrastuti Hidayat ${ }^{2}$, dan Meity Suradji Sinaga ${ }^{2}$ \\ ${ }^{1}$ Departemen Hama dan Penyakit Tumbuhan, Fakultas Pertanian, Universitas Padjadjaran \\ Jl. Raya Bandung-Sumedang KM 21, Jatinangor, Indonesia 45363 \\ ${ }^{2}$ Departemen Proteksi Tanaman, Fakultas Pertanian, Institut Pertanian Bogor, \\ Jl. Kamper Kampus IPB Dramaga, Bogor 16680 \\ *Email: s.hartati@unpad.ac.id
}

\begin{tabular}{lrc}
\hline \multicolumn{2}{c}{ INFO ARTIKEL } & ABSTRACT/ABSTRAK \\
\hline Diterima: & $13-06-2021$ & \\
Direvisi: & $28-07-2021$ & Identificaton of Potential Yeast Isolates as Antagonistic Agents and Testing of \\
Dipublikasi:11-08-2021 & Their Ability to Produce Hemolysin Toxin
\end{tabular}

Keywords:

words:

Aureobasidium

pullulans,

Hemolysin toxin,

Molecular

identification,

Pseudozyma,

Rhodotorula

minuta

Kata Kunci:

Aureobasidium

pullulans,

Identifikasi

molekuler,

Pseudozyma,

Rhodotorula minuta,

Toksin hemolisin
Yeast identification can be done conventionally and molecularly. Conventional identification requires long period of time to complete and has a subjective interpretation. Results of molecular method will be more accurate and takes a shorter time compared to conventional method. Antagonistic yeasts as biocontrol agents should has to be safe to the nontarget organisms when they are applied in the field. This study was objected to molecularly identify some antagonistic potential yeast isolates, and to evaluate their risk on mammals. Fifteen yeast isolates were evaluated for their potential antagonistic to Colletotrichum acutatum, the causal agent of anthracnose on chili. The molecular identification was carried out by PCR method using ITS1 and ITS4 primers. The yeast isolates were cultured on Yeast Malt Extract Broth (YMB) and Potato Dextrose Agar (PDA). To study for their risk on mammals, the isolates were cultured on blood agar base (Oxoid CM55) added with sheep blood 5\%. The molecular identification results showed that the isolates were successfully amplified by ITS1 and ITS4 primers, the fragment size were $500-800 \mathrm{pb}$. The sequencing results were six yeast spesies, i.e. Candida tropicalis, Rhodotorula minuta, Aureobasidium pullulans, Pseudozyma hubeiensis, Pseudozyma aphidis, and Pseudozyma shanxiensis. All yeast isolates tested were not produce hemolysin toxin, therefore they were suspected not pathogenic to human.

Identifikasi khamir dapat dilakukan secara konvensional maupun molekuler. Identifikasi secara konvensional membutuhkan waktu yang lama dan interpretasi hasilnya seringkali bersifat subyektif. Sementara identifikasi khamir dengan metode molekuler dapat memberikan hasil yang lebih akurat dan cepat. Khamir yang berperan sebagai agens antagonis harus aman terhadap organisme nontarget agar dapat diaplikasikan di lapangan. Penelitian ini bertujuan untuk mengidentifikasi isolat-isolat khamir berpotensi antagonis dengan metode molekuler dan mengetahui kemampuan khamir dalam menghasilkan hemolisin sebagai salah satu indikator potensi resiko terhadap mamalia. Identifikasi dan pengujian kemampuan khamir dalam menghasilkan hemolisin dilakukan pada 15 isolat khamir berpotensi antagonis terhadap patogen antraknosa cabai (Colletotrichum acutatum). Identifikasi khamir dilakukan secara molekuler dengan PCR menggunakan primer ITS1 dan ITS4. Penyediaan khamir menggunakan media Yeast Malt Extract Broth (YMB) dan Potato Dextrose 
Agar (PDA). Pengujian kemampuan khamir dalam menghasilkan hemolisin menggunakan media blood agar base (Oxoid CM55) ditambah darah domba 5\%. Hasil identifikasi menunjukkan bahwa isolat khamir dapat teramplifikasi dengan primer ITS1 dan ITS4 dengan ukuran fragmen produk antara $500-800 \mathrm{pb}$. Hasil analisis sekuensing didapatkan 6 spesies khamir yaitu Candida tropicalis, Rhodotorula minuta, Aureobasidium pullulans, Pseudozyma hubeiensis, Pseudozyma aphidis, dan Pseudozyma shanxiensis. Uji kemampuan khamir dalam menghasilkan hemolisin menunjukkan bahwa seluruh khamir yang diuji tidak menghasilkan toksin hemolisin sehingga diduga isolat-isolat tersebut tidak patogenik terhadap manusia.

\section{PENDAHULUAN}

Khamir merupakan salah satu mikroorganisme yang memiliki potensi tinggi sebagai agens biokontrol. Penggunaan khamir sebagai agens biokontrol patogen pada komoditas pra- dan pascapanen pada saat ini telah dikembangkan. Beberapa spesies khamir telah dilaporkan dapat mengendalikan patogen tanaman seperti Candida sake (Arrarte et al., 2017; CalvoGarrido et al., 2013; Carbo et al., 2018), Candida subhashii (Hilber-Bodmer et al., 2017), Aureobasidium pullulans (Bozoudi \& Tsaltas, 2018; Di Francesco et al., 2014; Freimoser et al., 2019), Metschnikowia fructicola dan Metschnikowia pulcherrima (Hilber-Bodmer et al., 2017; Parafati et al., 2015), Pichia spp. (Haïssam, 2011; Sugiprihatini et al., 2011) dan lain-lain. Khamir berpotensi antagonis tersebut dapat diisolasi dari berbagai habitat karena khamir memiliki rentang fisiologi yang luas, sehingga mampu tumbuh dalam kisaran lingkungan yang luas pula. Hal ini disebabkan oleh kemampuan metabolisme khamir di antaranya dalam proses asimilasi, fermentasi dan oksidasi (Kurtzman \& Fell, 2012).

Identifikasi mikroorganisme dalam ilmu penyakit tumbuhan memegang peran yang sangat penting. Identifikasi tersebut perlu dilakukan baik terhadap mikroorganisme penyebab penyakit maupun terhadap agens antagonis. Identifikasi mikroorganisme patogenik dibutuhkan dalam menentukan penyebab suatu penyakit tanaman, sehingga dapat dilakukan tindakan pengendalian yang tepat terhadap mikroorganisme patogenik tersebut. Sementara identifikasi agens antagonis juga dibutuhkan dalam menentukan mikroorganisme yang dapat digunakan dalam pengendalian hayati suatu penyakit, supaya dapat dilakukan pengujian maupun aplikasinya di lapangan dengan tepat.
Identifikasi khamir dapat dilakukan secara konvensional dan molekuler. Identifikasi khamir secara konvensional dilakukan berdasarkan morfologi, fisiologi dan biokimia (Kurtzman \& Fell, 2012). Akan tetapi, identifikasi khamir berdasarkan morfologi sulit dilakukan karena secara morfologi khamir sulit dibedakan. Hal ini disebabkan khamir memiliki karakter morfologi yang sederhana dan tidak mempunyai banyak variasi, sehingga karakter morfologi tidak dapat digunakan untuk identifikasi sampai tingkat spesies (Guarro et al., 1999). Identifikasi khamir secara konvensional juga dapat dilakukan berdasarkan sifat fisiologi dan biokimianya. Metode identifikasi berdasarkan karakter fisiologi dan biokimia umum dilakukan untuk khamir. Namun, identifikasi secara fisiologi dan biokimia memiliki kelemahan di antaranya memerlukan waktu pengujian yang lama, membutuhkan interpretasi subyektif dan karakter fisiologi dan biokimia jenis khamir yang berkerabat dekat seringkali identik sehingga dapat menyebabkan kesalahan dalam identifikasi (Daniel \& Meyer, 2003). Kelemahan metode konvensional dalam mengidentifikasi khamir dapat diatasi dengan menggunakan metode molekuler. Identifikasi khamir dengan metode molekuler dapat memberikan hasil yang lebih akurat dibandingkan dengan metode konvensional. Berbagai teknik deteksi dan identifikasi organisme secara molekuler telah dikembangkan antara lain melalui teknik polymerase chain reaction (PCR). PCR adalah metode reaksi berantai yang merupakan suatu metode enzimatis untuk melipatgandakan secara eksponensial suatu sekuen nukleotida tertentu dengan cara in vitro. Teknik PCR pada awal perkembangannya hanya digunakan untuk melipatgandakan molekul DNA, tetapi kemudian dikembangkan lebih lanjut sehingga dapat digunakan pula untuk melipatgandakan dan 
melakukan kuantifikasi molekul mRNA. Teknik PCR digunakan untuk analisis dan berbagai macam manipulasi genetik dan memiliki sensitivitas yang tinggi, serta lebih efisien.

Selain berperan sebagai agens antagonis, khamir juga diketahui dapat menjadi patogen baik pada tanaman, hewan dan manusia (Matteson Heidenreich et al., 1997). Salah satu kriteria agens antagonis dapat diaplikasikan di lapangan adalah apabila agens antagonis tersebut aman terhadap organisme nontarget. Oleh karena itu, isolat khamir yang telah diketahui berpotensi sebagai agens antagonis perlu diuji potensi resikonya terhadap organisme nontarget. Potensi risiko khamir terhadap nontarget, misalnya terhadap mamalia dapat diketahui melalui uji pembentukan toksin hemolisin. Toksin hemolisin adalah toksin yang dapat melisis sel darah merah mamalia. Pembentukan toksin hemolisin pada media agar darah dapat digunakan untuk mengetahui potensi patogenik khamir terhadap mamalia (Luo et al.,
2001; Suardana dkk., 2014). Penelitian ini bertujuan untuk mengidentifikasi isolat-isolat khamir berpotensi antagonis dengan metode molekuler dan mengetahui potensi resikonya terhadap mamalia dengan mendeteksi kemampuannya dalam menghasilkan toksin hemolisin.

\section{BAHAN DAN METODE}

\section{Identifikasi Khamir secara Molekuler}

Identifikasi khamir secara molekuler dilakukan di Laboratorium Virologi Tumbuhan Departemen Proteksi Tanaman IPB dan Laboratorium Biomolekuler Balai Uji Terap Teknik dan Metode Karantina Pertanian (BUTTMKP) Bekasi. Identifikasi khamir antagonis dilakukan dengan PCR menggunakan primer umum dengan pasangan forward primer ITS1 (5'-TCC GTA GGT GAA CCT GCG G-3') dan reverse primer ITS4 (5'TCC TCC GCT TAT TGA TAT GC-3') (Gambar 1) menurut metode Mirhendi et al. (2007).

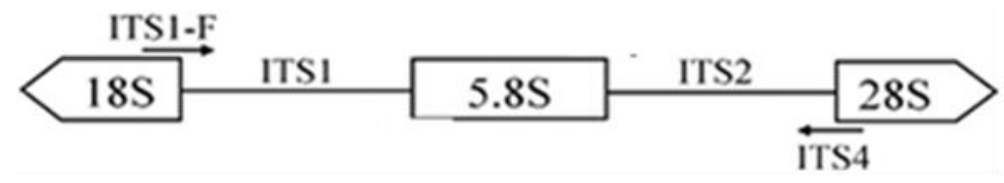

Gambar 1. Bagan disain primer ITS 1 dan ITS 4 pada daerah gen ribosomal DNA

\section{Penyediaan Isolat Khamir}

Isolat khamir yang digunakan dalam penelitian ini sebanyak 15 isolat yaitu Dmg 2 BEP, Dmg 11 DEP, Dmg 16 BEP, Dmg 18 BEP, Dmg 20 DEP, Dmg 23 DEP, Dmg 27 BEP, Dmg 28 DEP, Dmg 29 DEP, Dmg 30 DEP, Dmg 32 DEP, Lm 6 BE, Lm $13 \mathrm{BE}$, SG $25 \mathrm{BE}$, dan SG $53 \mathrm{BE}$. Isolat khamir tersebut telah diisolasi dari tanaman cabai dan telah diketahui memiliki potensi sebagai agens antagonis Colletotrichum acutatum penyebab penyakit antraknosa cabai pada penelitian sebelumnya (Hartati, 2016). Isolat khamir yang diidentifikasi diremajakan dalam media Yeast Malt Extract Broth (YMB), selanjutnya ditumbuhkan pada media Potato Dextrose Agar (PDA). Khamir berumur 5 hari digunakan untuk identifikasi.

\section{Ekstraksi Total Genomik DNA Khamir}

Tolal genomik DNA khamir diekstraksi dengan menggunakan FastDNA SPIN Kit (MPBio Thermoscientific). Biakan khamir berumur 5 hari pada media PDA diambil sebanyak 1 lup, dimasukkan dalam lysing matrix tube yang berisi 1 ml buffer Kit CLS-Y. Khamir dan buffer dihomogenasi dengan Super FastPrep-1 (MPBio Thermoscientific), selanjutnya disentrifugasi dengan kecepatan $12.000 \mathrm{rpm}$ selama 10 menit. Supernatan diambil $\pm 800 \mu \mathrm{l}$ dan dipindahkan ke microtube 2 $\mathrm{ml}$. Supernatan ditambah dengan binding matrix sebanyak volume supernatan, selanjutnya dicampur dengan cara dibolak-balik dan diinkubasi pada suhu ruang selama 5 menit. Setengah dari volume supernatan dan binding matrix $\left(\begin{array}{lll} \pm & 700 & \mu l\end{array}\right)$ dipindahkan ke tube spin filter dan disentrifugasi dengan kecapatan $12.000 \mathrm{rpm}$ selama 1 menit, selanjutnya larutan dalam tube bagian bawah dibuang. Tahap ini diulang terhadap sisa larutan yang ada. Pelet yang didapatkan ditambah dengan $500 \mu \mathrm{l}$ SEWS-M dan dihomogenisasi dengan mikrotip. Pelet tersebut disentrifugasi dengan kecepatan $12.000 \mathrm{rpm}$ selama 1 menit, supernatan dibuang, tube diganti dengan yang baru. Tanpa penambahan apapun, pelet disentrifugasi kembali dengan kecepatan 12.000 selama 2 menit. Tube diganti dengan tube berukuran $1,5 \mathrm{ml}$ yang baru. DNA yang didapatkan dielusi dengan $100 \mu \mathrm{L}$ DES 
dan diinkubasi pada suhu $55{ }^{\circ} \mathrm{C}$ selama 5 menit. DNA disentrifugasi kembali dengan kecepatan $12.000 \mathrm{rpm}$ selama 1 menit. Spin filter yang berisi kotoran dibuang. DNA berbentuk cairan bening disimpan pada suhu $-20{ }^{\circ} \mathrm{C}$ untuk penyimpanan jangka panjang atau pada $4{ }^{\circ} \mathrm{C}$ untuk penyimpanan jangka pendek.

\section{Amplifikasi Gen ITS1 dan ITS4 Khamir dengan PCR} Perlakuan Amplifikasi DNA khamir menggunakan mesin PCR (Gene Amp®, PCR System 9700) dengan primer umum ITS1 dan ITS4. Larutan DNA sebanyak $2 \mu \mathrm{l}( \pm 500 \mathrm{ng})$ diamplifikasi dengan volume reaksi $25 \mu \mathrm{l}$ yang terdiri dari $12,5 \mu \mathrm{l}$ master mix (Thermoscientific), $1 \mu \mathrm{l}(10 \mathrm{pmol})$ forward primer (ITS1) (5'-TCC GTA GGT GAA CCT GCG G-3'), $1 \mu \mathrm{l}(10 \mathrm{pmol})$ reverse primer (ITS4) (5'TCC TCC GCT TAT TGA TAT GC-3'), dan 8,5 $\mu \mathrm{l}$ dH2O. Amplifikasi dilakukan dengan mesin PCR yang dimulai dengan denaturasi awal $95^{\circ} \mathrm{C}$ selama 5 menit. Selanjutnya program PCR mencakup denaturasi $95^{\circ} \mathrm{C}$ selama 45 detik, annealing $55^{\circ} \mathrm{C}$ selama 30 detik dan extension $72^{\circ} \mathrm{C}$ selama 1 menit 30 detik diulang sebanyak 35 siklus. Program tersebut diakhiri dengan final extension $72^{\circ} \mathrm{C}$ selama 7 menit. Elektroforesis dilakukan dalam 1,5\% w/v gel agarose (TopVision, Frementas) dengan marker GeneRuler $100 \mathrm{pb}$ DNA Ladder (Fermentas) dan diwarnai dengan ethidium bromide. Hasil PCR disikuen di PT First Base Genetica Science menggunakan pasangan primer ITS1 dan ITS4. Analisis homologi nukleotida khamir menggunakan Basic Local Alignment Search Tool (BLAST) pada situs National Center for Biotechnology Information (NCBI) di www.blast.ncbi.nlm.nih.gov.

Pengujian Kemampuan Khamir dalam Menghasilkan Hemolisin
Pengujian kemampuan khamir dalam menghasilkan hemolisin dilakukan untuk mengetahui apakah isolat khamir yang diuji menghasilkan toksin hemolisin. Pengujian dilakukan dengan menggoreskan isolat khamir umur 5 hari pada media blood agar base (Oxoid CM55) yang telah ditambah darah domba $5 \%$, kemudian diinkubasi pada suhu ruang selama 24 sampai 48 jam. Pengujian menunjukkan hasil positif produksi hemolisin apabila terbentuk zona bening di sekitar koloni setelah inkubasi (Suardana et al., 2014). Sebagai kontrol positif, digunakan bakteri endofit ubi jalar isolat $\operatorname{EAM}(7), \operatorname{EAM}(8), \operatorname{EAM}(9), \operatorname{EAM}(10)$, $\operatorname{EUM}(13)$ dan EBM (8) (koleksi Tuminem Laboratorium Nematologi Tumbuhan IPB) yang diketahui menghasilkan hemolisin.

\section{HASIL DAN PEMBAHASAN}

\section{Identifikasi Khamir secara Molekuler}

Identifikasi spesies 15 isolat khamir yang berpotensi antagonis terhadap $C$. acutatum cabai pada gen 18S, ITS1, gen 5,8S, ITS2, dan gen $28 \mathrm{~S}$ ribosomal DNA (Gambar 1) menunjukkan bahwa 15 isolat khamir tersebut teramplifikasi dengan primer ITS1 dan ITS4 dengan ukuran fragmen produk antara $500-800 \mathrm{pb}$ (Gambar 2). Tiga DNA isolat khamir yaitu Dmg 2 BEP, Lm 6 BE, Lm 13 BE, teramplifikasi dengan primer ITS1 dan ITS4 dengan ukuran fragmen produk $500 \mathrm{pb}$. Empat DNA isolat khamir yaitu Dmg 11 DEP, Dmg 29 DEP, Dmg 30 DEP dan Dmg 16 DEP teramplifikasi dengan primer ITS1 dan ITS4 dengan ukuran fragmen produk 600 pb. Delapan DNA khamir yaitu Dmg 18 BEP, Dmg 20 DEP, Dmg 23 DEP, Dmg 27 BEP, Dmg 32 DEP, Dmg 28 DEP, SG 25 BE dan SG 53 BE teramplifikasi dengan ukuran fragmen produk $800 \mathrm{pb}$ (Gambar 2).

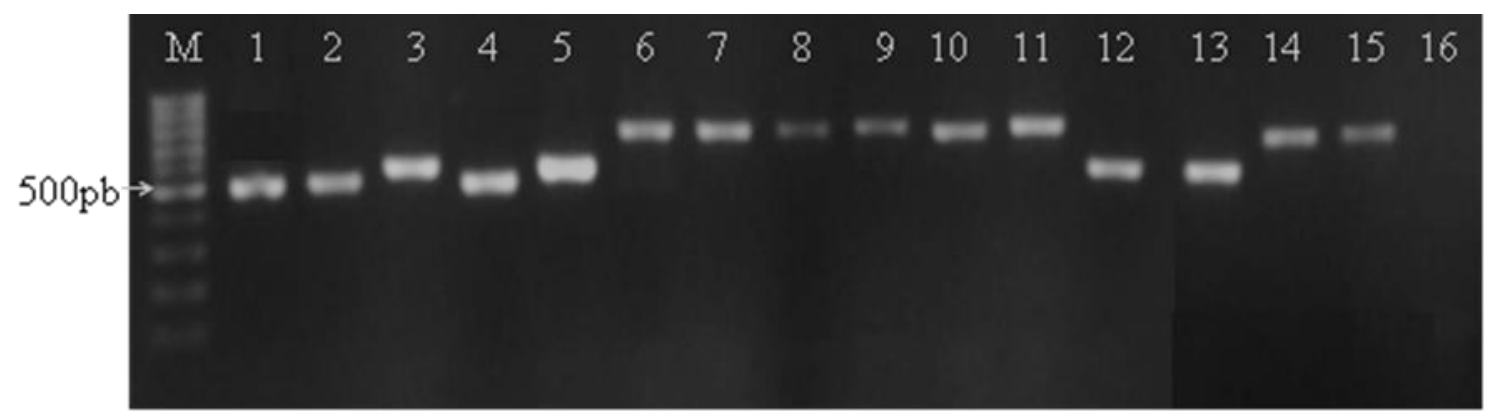

Gambar 2. Visualisasi DNA khamir hasil amplifikasi menggunakan primer ITS1 dan ITS4 dengan penanda DNA 100 pb. M: marker 100 pb, 1. Dmg 2 BEP, 2. Lm 6 BE, 3. Dmg 11 DEP, 4. Lm 13 BE, 5. Dmg 16 BEP, 6. Dmg 18 BEP, 7. Dmg 20 DEP, 8. Dmg 23 DEP, 9. SG 25 BE, 10. Dmg 27 BEP, 11. Dmg 28 DEP, 12. Dmg 29 DEP, 13. Dmg 30 DEP, 14. Dmg 32 DEP, 15. SG 53 BE, 16. kontrol (-) 
Berdasarkan hasil penelitian ini diketahui bahwa 15 isolat khamir antagonis yang berpotensi sebagai agens antagonis penyebab antraknosa cabai berhasil diidentifikasi dengan menggunakan primer umum ITS1 dan ITS4 pada rDNA. Posisi daerah yang diamplifikasi adalah sebagian gen 18S, ITS1, gen 5,8S, ITS2, dan sebagian gen 28S ribosomal DNA (Gambar 1). Gen-gen yang terdapat dalam ribosomal DNA (rDNA) adalah kelompok gen yang umumnya digunakan untuk mengidentifikasi khamir dengan cepat dan akurat (Kutrzman \& Robnet, 2003). Sekuen daerah internal transcribed spacers (ITS) dari rDNA dapat digunakan untuk mengidentifikasi khamir. Daerah ITS rDNA merupakan daerah noncoding yang memiliki laju mutasi tinggi, sehingga memiliki variasi urutan nukleotida yang tinggi antar jenis (James \& Stratford, 2003; Ciardo, 2006; Purnamasari dkk., 2012). Daerah ITS rDNA dapat digunakan untuk identifikasi jenis khamir yang berkerabat sangat dekat (James \& Stratford, 2003).

Tahap ekstraksi DNA yang dilakukan dari koloni khamir berumur 5 hari sangat tepat, karena pada umur tersebut khamir telah memasuki fase log (fase eksponensial). Kaitan fase log khamir dengan keberhasilan ekstraksi dan identifikasi adalah pada fase log didapatkan kandungan DNA tertinggi suatu mikroorganisme. Hal ini disebabkan fase log merupakan fase pertumbuhan populasi organisme yang paling aktif.
Hasil analisis sekuensing isolat khamir Lm 13 BE, Lm 6 BE, Dmg 30 DEP, Dmg 29 DEP, Dmg 11 DEP, Dmg 2 BEP, Dmg 16 BEP, Dmg 18 BEP, Dmg 20 DEP, Dmg 23 DEP, SG 25 BE, Dmg 27 BEP, Dmg 28 DEP, Dmg 32 DEP, dan SG 53 BE menunjukkan nilai homologi yang tinggi yaitu antara $94-100 \%$ dan nilai query cover antara 52100\%, kecuali Dmg 23 DEP nilai homologi hanya $73 \%$. Identifikasi 15 isolat khamir antagonis secara molekuler tersebut didapatkan 6 spesies khamir yaitu Candida tropicalis, Rhodotorula minuta, Aureobasidium pullulans, Pseudozyma hubeiensis, Pseudozyma aphidis, dan Pseudozyma shanxiensis (Tabel 1). Dua isolat khamir endofit SG 25 BE dan SG 53 BE menunjukkan nilai homologi yang tinggi dengan $P$. aphidis yaitu masing-masing sebesar $100 \%$. Nilai homologi yang tinggi juga ditunjukkan oleh isolat Dmg 11 DEP, Dmg 29 DEP, dan Dmg 30 DEP dengan $A$. pullulans yaitu berturut-turut sebesar 100, 99, 99\%. Tiga isolat khamir Lm $6 \mathrm{BE}$, Lm 13 BE, dan Dmg 2 BEP memiliki nilai homologi yang sama yaitu $99 \%$ dengan Ca. tropicalis. Lima isolat khamir epifit memiliki nilai homologi berkisar antara 73-98\% dengan $P$. hubeiensis yaitu Dmg 18 BEP, Dmg 20 DEP, Dmg 23 DEP, Dmg 27 BEP, dan Dmg 32 DEP, sedangkan isolat Dmg 16 BEP dan Dmg 28 DEP berturut-turut menunjukkan nilai homologi $96 \%$ dengan $\quad R$. minuta dan $94 \%$ dengan P. shanxiensis (Tabel 1).

Tabel 1. Identifikasi isolat khamir berpotensi antagonis dengan sekuensing gen ITS1 dan ITS4 rDNA

\begin{tabular}{lllcl}
\hline Isolat khamir & Asesi & Asal isolat GenBank & $\begin{array}{c}\text { Homologi } \\
(\%) / \mathrm{C}^{\mathrm{a}}\end{array}$ & \multicolumn{1}{c}{ Spesies } \\
\hline Dmg 11 DEP & JQ235061.1 & Populus euphratica, China & $100 / 57$ & Aureobasidium pullulans \\
Dmg 29 DEP & JQ235061.1 & Populus euphratica, China & $99 / 73$ & Aureobasidium pullulans \\
Dmg 30 DEP & JQ235061.1 & Populus euphratica, China & $99 / 54$ & Aureobasidium pullulans \\
Lm 6 BE & AF321539.1 & Buah jeruk, Spanyol & $99 / 56$ & Candida tropicalis \\
Lm 13 BE & AF321539.1 & Buah jeruk, Spanyol & $99 / 52$ & Candida tropicalis \\
Dmg 2 BEP & AF321539.1 & Buah jeruk, Spanyol & $99 / 72$ & Candida tropicalis \\
SG 25 BE & KF443199.1 & Daun mulberi, China & $100 / 100$ & Pseudozyma aphidis \\
SG 53 BE & KF443199.1 & Daun mulberi, China & $100 / 100$ & Pseudozyma aphidis \\
Dmg 16 BEP & HQ832824.1 & Camellia sinensis, China & $96 / 53$ & Rhodotorula minuta \\
Dmg 28 DEP & DQ008956.1 & Daun, China & $94 / 98$ & Pseudozyma shanxiensis \\
Dmg 18 BEP & DQ008954.1 & Daun, China & $96 / 98$ & Pseudozyma hubeiensis \\
Dmg 20 DEP & DQ008954.1 & Daun, China & $98 / 94$ & Pseudozyma hubeiensis \\
Dmg 23 DEP & DQ008954.1 & Daun, China & $73 / 92$ & Pseudozyma hubeiensis \\
Dmg 27 BEP & DQ008954.1 & Daun, China & $98 / 58$ & Pseudozyma hubeiensis \\
Dmg 32 DEP & DQ008954.1 & Daun, China & $95 / 97$ & Pseudozyma hubeiensis
\end{tabular}

Keterangan: a Persentase homologi fragmen DNA dianalisis dengan program BLAST dan sekuen dibandingkan dengan database dari NCBI, daerah gen ribosomal DNA yang digunakan adalah ITS1 \& ITS4, Qc: Query cover 
Isolat-isolat khamir yang diisolasi dari daun dan buah cabai berdasarkan hasil penelitian ini diketahui didominasi oleh spesies dari genus Pseudozyma sebanyak 8 isolat yaitu $P$. hubeiensis, $P$. aphidis, dan $P$. shanxiensis. Lima isolat khamir diidentifikasi sebagai $P$. hubeiensis. Berdasarkan penelitian sebelumnya isolat yang teridentifikasi sebagai spesies $P$. hubeiensis dan $P$. shanxiensis merupakan spesies epifit, sedangkan isolat yang teridentifikasi sebagai $P$. aphidis merupakan spesies endofit (Hartati, 2016). Hal ini menunjukkan bahwa anggota genus Pseudozyma dapat hidup baik pada permukaan maupun di dalam jaringan tanaman.

Pseudozyma spp. adalah khamir yang memiliki bentuk dimorfik yang termasuk dalam filum Basidiomycota, kelas Ustilaginomycetes, ordo Ustilaginales. Pseudozyma umumnya bersifat epifit atau saprofit dan tidak bersifat patogenik terhadap tanaman, hewan dan serangga (Avis \& Belanger, 2002). Genus Pseudozyma telah dilaporkan berpotensi sebagai agens biokontrol (Buxdorf et al., 2013; Gafni et al., 2015). Spesies P. aphidis (Henninger \& Windisch) Boekhout mampu menekan powdery mildew yang disebabkan oleh Podosphaera xanthii (Gafni et al., 2015). P. aphidis juga dilaporkan memiliki kemampuan menekan Botrytis cinerea pada tomat (Buxdorf et al., 2013).

Tiga isolat khamir yang terdiri dari 1 isolat epifit (Dmg 2 BEP) dan 2 isolat endofit ( $\operatorname{Lm} 6$ BE dan $\mathrm{Lm} 13 \mathrm{BE})$ yang didapatkan dari penelitian sebelumnya diidentifikasi sebagai Ca. tropicalis (Hartati, 2016). Isaeva et al. (2010) melaporkan bahwa terdapat persamaan spesies khamir endofit yang diisolasi dari dalam jaringan buah dengan spesies khamir epifit yang diisolasi dari permukaan buah. Namun demikian, terdapat beberapa perbedaan dalam sifat-sifat komunitas khamir epifit dan endofit (Isaeva et al., 2010). Khamir Ca. tropicalis telah dilaporkan memiliki potensi sebagai agens antagonis terhadap beberapa patogen (Sriram \& Poornachanddra, 2013; Fahriani \& Wiyono, 2018). Khamir Ca. tropicalis yang diisolasi dari permukaan buah mangga mampu menekan penyakit busuk buah pada mangga (Sriram \& Poornachanddra, 2013). Khamir Ca. tropicalis juga dilaporkan mampu meningkatkan pertumbuhan tanaman padi (Amprayn et al., 2012). Spesies Ca. tropicalis (Castellani) Berkhout diklasifikasikan ke dalam filum Ascomycota, ordo Saccharomycetales.

Isolat Dmg 16 BEP yang diidentifikasi sebagai $R$. minuta didapatkan dari penelitian sebelumnya dari permukaan buah cabai sebagai epifit. Isaeva et al. (2010) melaporkan bahwa spesies dari genus Rhodotorula lebih sering didapatkan dari permukaan buah dibandingkan dari jaringan tanaman. Rhodotorula merupakan genus khamir yang dapat ditemukan dimana-mana dan bersifat saprofit (Sjamsuridzal et al., 2010). Rhodotorula telah digunakan sebagai penghasil karoten, genus ini juga dilaporkan berperan sebagai agens biokontrol patogen tanaman (Patiño-Vera et al., 2005; Fahriani \& Wiyono, 2018; Setiawan et al., 2020). Khamir $R$. minuta (Saito) F.C. Harrison diklasifikasikan ke dalam filum Basidiomycota, ordo Sporidiobolales (Kurtzman \& Fell, 2012).

Tiga isolat khamir epifit dari permukaan daun cabai yang didapatkan dari penelitian sebelumnya yaitu Dmg 11 DEP, Dmg 29 DEP, dan Dmg 30 DEP diidentifikasi sebagai $A$. pullulans. Spesies $A$. pullulans (de Bary) Arnaud merupakan anggota filum Ascomycota, ordo Dothideales. Spesies ini sering disebut sebagai black yeast dan pada umumnya ditemukan sebagai epifit di permukaan tanaman, dapat juga sebagai endofit di dalam jaringan tanaman (Osono, 2008; Martini et al., 2009). Spesies $A$. pullulans bersifat kosmopolit, mengoloni permukaan daun, dan memiliki kemampuan beradaptasi dengan baik di filosfer (Singh et al., 2015). Spesies $A$. pullulans dikenal baik dalam industri dan pertanian (Arzanlou, 2014). Dalam bidang pertanian, $A$. pullulans dikenal sebagai agens biokontrol (Di Francesco et al., 2017; Hartati et al., 2015; Mari et al., 2012). Spesies ini juga dikenal menghasilkan produk komersial, pullulan, biodegradable extracellular polysaccharide, dan berpotensi sebagai agens biokontrol patogen pascapanen (Singh et al., 2015; Zalar et al., 2008). Khamir A. pullulans menunjukkan polimorfisme, yaitu dapat tumbuh sebagai khamir dengan membentuk sel tunas atau membentuk miselia (Singh et al., 2015).

\section{Kemampuan Khamir dalam Menghasilkan Hemolisin}

Uji kemampuan khamir dalam meghasilkan hemolisin merupakan salah satu parameter uji potensi resiko khamir terhadap mamalia. Hasil uji pada penelitian ini menunjukkan bahwa seluruh khamir antagonis tidak menghasilkan toksin hemolisin. Hal ini ditunjukkan dengan tidak terbentuknya zona bening maupun perubahan warna di sekitar koloni khamir antagonis pada media agar darah baik setelah 24 maupun 48 jam (Gambar 3). Pembentukan toksin hemolisin ditandai dengan terbentuknya zona hemolisis di sekitar 
koloni mikroorganisme uji. Zona hemolisis yang ditandai dengan pembentukan zona bening pada media agar darah di sekitar koloni mikroorganisme uji menunjukkan bahwa mikroorganisme tersebut menghasilkan beta hemolisin (Luo et al. 2001). Toksin beta hemolisin mampu menghancurkan sel darah merah dengan sempurna (Luo et al. 2001). Alpha hemolisin ditunjukkan oleh adanya zona berwarna kehijauan di sekitar koloni mikroorganisme uji pada media agar darah (Luo et al. 2001). Alpha hemolisin merubah warna media agar darah dengan mereduksi hemoglobin menjadi meta hemoglobin (Luo et al. 2001). Kontrol positif dengan menggunakan bakteri endofit ubi jalar isolat $\operatorname{EAM}(7), \operatorname{EAM}(8), \operatorname{EAM}(9), \operatorname{EAM}(10), \operatorname{EUM}(13)$ dan EBM (8) menunjukkan terbentuknya zona bening di sekitar koloni bakteri pada media agar darah pada 48 jam setelah perlakuan. Hasil pengujian potensi resiko khamir berpotensi antagonis dengan media agar darah dalam penelitian ini menunjukkan bahwa isolat khamir tersebut diduga tidak berpotensi patogenik terhadap mamalia berdasarkan ketidakmampuannya dalam menghasilkan toksin hemolisin.

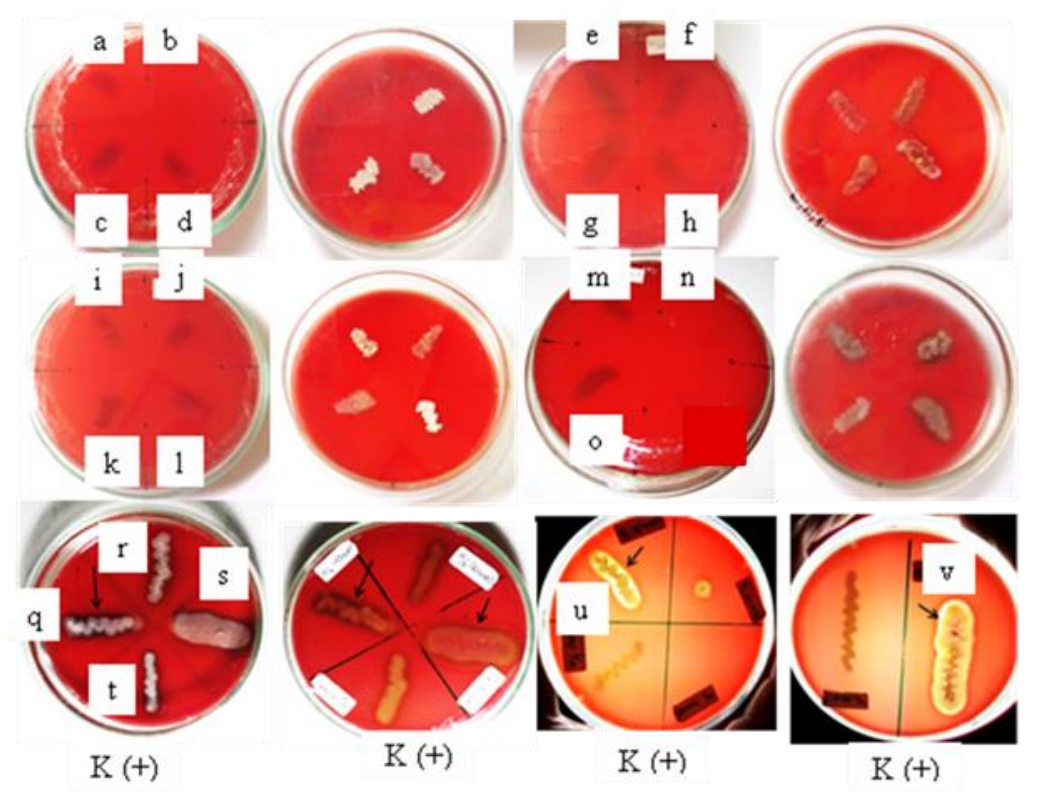

Gambar 1. Uji hemolisis isolat khamir pada media agar darah a. Dmg 2 BEP, b. SG 53 BE, c. Lm 13 BE, d. SG 25 BE, e. Dmg 20 DEP, f. Dmg 16 DEP, g. Lm 6 BE, h. Dmg 18 DEP, i. Dmg 23 DEP, j. Dmg 32 DEP, k. Dmg 28 DEP, l. Dmg 27 BEP, m. Dmg 30 DEP, n. Dmg 11 DEP, o. Dmg 29 DEP, K(+): kontrol positif bakteri endofit ubi jalar q. $\operatorname{EAM}(10)$, r. $\operatorname{EAM}(7)$, s. $\operatorname{EAM}(8)$, t. $\operatorname{EAM}(9)$, u. $\operatorname{EBM}$

(8), v. $\operatorname{EUM}(13)$

\section{SIMPULAN}

Berdasarkan hasil identifikasi secara molekuler terhadap 15 isolat khamir berpotensi antagonis diperoleh 6 spesies khamir yaitu Candida tropicalis, Rhodotorula minuta, Aureobasidium pullulans, Pseudozyma hubeiensis, Pseudozyma aphidis dan Pseudozyma shanxiensis. Dua spesies khamir termasuk dalam filum Ascomycota yaitu Ca. tropicalis dan $A$. pullulans, dan 4 spesies termasuk dalam filum Basidiomycota yaitu $R$. minuta, $P$. hubeiensis, $P$. aphidis dan $P$. shanxiensis. Berdasarkan uji kemampuan khamir dalam meghasilkan hemolisin diketahui bahwa khamir antagonis tersebut tidak menghasilkan hemolisin sehingga berpotensi tidak bersifat patogenik terhadap mamalia.

\section{DAFTAR PUSTAKA}

Amprayn, K, MT Rose, M Kecskés, L Pereg, HT Nguyen, and IR Kennedy. 2012. Plant growth promoting characteristics of soil yeast (Candida tropicalis $\mathrm{HY}$ ) and its effectiveness for promoting rice growth. Applied Soil Ecology. 61: 295-299.

Arrarte, E, G Garmendia, C Rossini, M Wisniewski, and S Vero. 2017. Volatile organic compounds produced by Antarctic strains of Candida sake play a role in the control of 
postharvest pathogens of apples. Biologycal Control. 109: 14-20.

Arzanlou, M. 2014. Molecular characterization of Aureobasidium species in Iran. Research in Molecular Medicinal. 2(2): 28-33.

Avis, TJ, and RR Bélanger . 2002. Mechanisms and means of detection of biocontrol activity of Pseudozyma yeasts against plant-pathogenic fungi. FEMS Yeast Research. 2(1): 5-8.

Bozoudi, D, and D Tsaltas. 2018. The Multiple and Versatile Roles of Aureobasidium pullulans in the Vitivinicultural Sector. Fermentation. 4(85): 1-15.

Buxdorf, K, I Rahat, A Gafni, and M Levy. 2013. The epiphytic fungus Pseudozyma aphidis induces jasmonic acid- and salicylic acid/nonexpressor of PR1-independent local and systemic resistance. Plant Physiology. 161: 2014-2022.

Calvo-Garrido, C, I Viñas, P Elmer, J Usall, and N Teixido. 2013. Candida sake CPA-1 and other biologically based products as potential control strategies to reduce sour rot of grapes. Letters in Applied Microbiology. 57: 356-361.

Carbo, A, R Torres, N Teixido, J Usall, A Medina, and N Magan. 2018. Impact of climate change environmental conditions on the resilience of diferent formulations of the biocontrol agent Candida sake CPA-1 on grapes. Letters in Applied Microbiology. 67(1): 2-8.

Ciardo, DE, G Schär, EC Böttger, M Altwegg, and PP Bosshard. 2006. Internal transcribed spacer sequencing versus biochemical profiling for identification of medically important yeasts. Journal of Clinical Microbiology. 44(1): 7784.

Daniel, HM, and W Meyer. 2003. Evaluation of ribosomal RNA and actin gene sequences for the identification of ascomycetous yeasts. International Journal of Food Microbiology. 86:61-78.

Di Francesco, A, F Milella, M Mari, and R Roberti. 2017. A preliminary investigation into Aureobasidium pullulans as a potential biocontrol agent against Phytophthora infestans of tomato. Biological Control. 114: 144-149.

Di Francesco, A, L Ugolini, L Lazzeri, and M Mari. 2014. Production of volatile organic compounds by Aureobasidium pullulans as a potential mechanism of action against postharvest fruit pathogens. Biological Control. 81: 8-14.

Fahriani, U, dan S Wiyono. 2018. Seleksi khamir antagonis sebagai agens biokontrol penyakit bercak daun Cercospora pada Anggrek Dendrobium. Communications of Horticultural Journal. 2(2): 46-53.

Freimoser, FM, MP Rueda-Mejia, B Tilocca, and Q Migheli. 2019. Biocontrol yeasts: mechanisms and applications. World Journal Microbiology Biotechnology. 35: 154.

Gafni, A, CE Calderon, R Harris, K Buxdorf, A Dafaberger, E Zelinger, and M Levy. 2015. Biological control of the cucurbit powdery mildew pathogen Podosphaera xanthii by means of the epiphytic fungus Pseudozyma aphidis and parasitism as a mode of action. Frontiers in Plant Science. 6:132-142.

Guarro, J, J Gene, and AM Stchigel. 1999. Developments in fungal taxonomy. Clinical Microbiology Reviews. 12: 454-500.

Haïssam, JM. 2011 Pichia anomala in biocontrol for apples: 20 years of fundamental research and practical application. Antonie van Leeuwenhoek. 99: 93-105.

Hartati, S, S Wiyono, SH Hidayat, and MS Sinaga. 2015. Mode of action of yeast-like fungus Aureobasidium pullulans in controlling anthracnose of postharvest chili. International Journal of Innovative and Applied Research. 4531: 253-263.

Hartati, S. 2016. Khamir sebagai Agens Biokontrol Antraknosa (Colletotrichum acutatum J. H. Simmonds) pada Cabai Pascapanen. [Disertasi]. Sekolah Pascasarjana Institut Pertanian Bogor: Bogor.

Hilber-Bodmer, M, M Schmid, CH Ahrens, and FM Freimoser. 2017. Competition assays and physiological experiments of soil and phyllosphere yeasts identify Candida subhashii as a novel antagonist of flamentous fungi. BMC Microbiology. 17: 4.

Isaeva, OV, AM Glushakova, SA Garbuz, AV Kachalkin, and IY Chernov. 2010. Endophytic yeast fungi in plant storage tissues. Biology Bulletin. 37(1): 26-34.

James, SA, and M Stratford. 2003. Spoilage Yeast with Emphasis on the Genus Zygosaccharomyces. Dalam: Boekhout T, Robert V (eds). 2003. Yeast in Food. Cambridge (GB): Woodhead Publishing Limited. p.171-191. 
Kurtzman, CP, and JW Fell. 2012. The Yeasts: $A$ Taxonomic Study. 5th ed. Amsterdam (NL): Elsevier Science Publishers.

Kurtzman, CP, and CJ Robnett. 2003. Phylogenetic relationships among yeasts of the 'Saccharomyces complex' determined from multigene sequence analyses. FEMS Yeast Research. 3: 417-432.

Luo, G, LP Samaranayake, and JYY Yau. 2001. Candida species exhibit differential in vitro hemolytic activities. Journal of Clinical Microbiology. 39(8): 2971-2974.

Martini, M, R Musetti, S Grisan, R Polizzotto, S Borselli, F Pavan, and R Osler. 2009. DNAdependent detection of the grapevine fungal endophytes Aureobasidium pullulans and Epicoccum nigrum. Plant Diseases. 93: 993998.

Mari, M, C Martini, A Spadoni, W Rouissi, and P Bertolini. 2012. Biocontrol of apple postharvest decay by Aureobasidium pullulans. Postharvest Biology and Technology. 73: 56-62.

Matteson Heidenreich, MC, MR Corral-Garcia, EA Momol, and TJ Burr. 1997. Russet of apple fruit caused by Aureobasidium pullulans and Rhodotorula glutinis. Plant Diseases. 81:337342.

Mirhendi, H, K Diba, A Rezaei, N Jalalizand, L Hosseinpur, and H Khodadadi. 2007. ColonyPCR is a rapid and sensitive method for DNA amplification in yeasts. Iranian Journal of Public Health. 36(1): 40-44.

Osono T. 2008. Endophytic and epiphytic phyllosphere fungi of Camellia japonica: seasonal and leaf age-dependent variations. Mycologia. 100(3): 387-391.

Parafati, L, A Vitale, C Restuccia, and G Cirvilleri. 2015. Biocontrol ability and action mechanism of food-isolated yeast strains against Botrytis cinerea causing post-harvest bunch rot of table grape. Food Microbiology. 47: 85-92.

Patiño-Vera, M, B Jimeñez, K Balderas, M Ortiz, R Allende, A Carrillo, and E Galindo. 2005. Pilot-scale production and liquid formulation of Rhodotorula minuta, a potential biocontrol agent of mango anthracnose. Journal of Applied Microbiology. 99: 540-550.

Purnamasari, MI, C Prihatna, AW Gunawan, and A Suwanto. 2012. Isolasi dan Identifikasi secara Molekuler Ganoderma spp. yang Berasosiasi dengan Penyakit Busuk Pangkal Batang di Kelapa Sawit. Jurnal Fitopatologi Indonesia. 8(1): 9-15.

Setiawan, W, S Wiyono, ET Tondok, A Kanti, and IM Sudiana. 2020. In vitro study of action mode of Rhodotorula minuta Dmg $16 \mathrm{BEP}$ as biocontrol agents on Alternaria solani. Jurnal Perlindungan Tanaman Indonesia. 24(1): 2833.

Singh, R, R Gaur, S Bansal, P Biswas, PK Pandey, and F Jamal. Aureobasidium pullulans - An industrially important pullulan producing black yeast. International Journal of Current Microbiology and Applied Science. 4(10): 605-622.

Sjamsuridzal, W, A Oetari, A Kanti, R Saraswati, C Nakashima, Y Widyastuti, and A Katsuhiko. 2010. Ecological and taxonomical perspective of yeast in Indonesia. Microbiology Indonesia 4: 60-68

Sriram, S, and SR Poornachanddra. 2013. Biological control of postharvest mango fruit rot caused by Colletotrichum gloeosporioides and Diplodia natalensis with Candida tropicalis and Alcaligenes feacalis. Indian Phytopathol. 66(4):375-380.

Suardana, IW, IH Utama, dan MH Wibowo. 2014. Identifikasi Escherichia coli O157:H7 dari feses ayam dan uji profil hemolisisnya pada media agar darah. Jurnal Kedokteran Hewan. 8(1): 1-5.

Sugiprihatini, D, S Wiyono, and Widodo. 2011. Selection of yeasts antagonists as biocontrol agent of mango fruit rot caused by Botryodiplodia theobromae. Microbiology Indonesia. 5(4): 154-159.

Zalar P, C Gostincar, GS de Hoog, V Ursic, M Sudhadham, and N Gunde-Cimerman. 2008. Redefinition of Aureobasidium pullulans and its varieties. Studies in Mycology. 61: 21-38. 